\title{
ANALISIS PENERAPAN TARIF PAKET PELAYANAN ESENSIAL (PPE) JAMKESMAS PADA PELAYANAN OPERASI CAESAREA KELAS III DI RUMAH SAKIT PKU MUHAMMADIYAH UNIT I YOGYAKARTA TAHUN 2009
}

\author{
Dian Alfiah, Rosyidah, Surahma Asti Mulasari \\ Fakultas Kesehatan Masyarakat, Universitas Ahmad Dahlan, Yogyakarta
}

\begin{abstract}
Background: The growth and developed hospital should be effectively and efficiency managed. This fact should be carried out in order to face strict competitions in the health world. The hospital can survive in facing the existing competitions by counting the previous hospital fee and using fee account model competitively. In PKU Muhammadiyah Unit I Yogyakarta, Set of Essential Services (SES) of caesarea operation fee, class III, and cost sharing between the hospital and the goverment are different. In this study, the researcher only counts caesarea operation fee for re-use in order to create low cost sharing. Up till now, the hospital party never counts those existing differences. This case will lead them to get a financial loss. By having this fact, the researcher was eager to know about cost sharing analysis of caesarea operation fee account, class III, in PKU Muhammadiyah Unit I Yogyakarta.

Methode: This was qualitative descriptive research which analyses the exact fee by using real cost method to know the difference of patient's fee toward the real fee in the hospital. Bisides that, interview method was applied to know the head of finance and Central Surgeon Installation (CSI) workers opinion.

Resulth: The result of Set of Essential Services (SES) fee of 'health insurance' toward caesarea operation was Rp 1.230.429, caesarea operation fee by using real cost method was Rp 3.764.388, in fact, the exact fee from RS PKU Muhammadiyah Unit I Yogyakarta was Rp 4.705.388. In conclusion, the final results were the difference of 'Set of Essential Services (SES) fee of 'health insurance' between real cost was Rp 2.533.959 and the difference of 'Set of Essential Services (SES) fee of 'health insurance' between the exact hospital costs was Rp 3.475.056.

Conclusion: The researcher has concluded that set of costs which is based on unit cost was higher that hospital cost recently. The highest cost was given for buying medicines and temporary materials. The hospital party has to decide the best strategy to reduce those differences.
\end{abstract}

Key words: cost sharing, real cost method, Set of Essential Services (SES) of caesarea operation fee, class III.

\section{PENDAHULUAN}

Kesehatan merupakan salah satu komponen penting yang paling mendapat perhatian di dalam sistem jaminan sosial. Undang-undang No.23 Tahun 1992, menjelaskan bahwa setiap orang mempunyai hak yang sama dalam memperoleh derajat kesehatan yang optimal. Pemerintah dalam hal ini bertugas menggerakkan peran serta masyarakat dalam penyelenggaraan kesehatan dan pembiayaan kesehatan, dengan memperhatikan fungsi sosial sehingga pelayanan kesehatan bagi masyarakat kurang mampu tetap terjamin. Peran pemerintah bertanggung jawab unuk mengatur sedemikian rupa sehingga setiap penduduk memiliki kesempatan yang sama (equal opportunities) terhadap kebutuhan pelayanan kesehatan yang di inginkan, tanpa memandang latar belakang agama, suku, jenis kelamin dan tingkat sosial ekonomi. ${ }^{1}$ Trisnantoro $(2005)^{2}$ menyatakan bahwa 
rumah sakit sebagai salah satu unit pelayanan kesehatan tindak lanjut untuk kasus rujukan menjadi harapan bagi keluarga miskin untuk mendapat pelayanan yang bermutu.

Rumah sakit yang tumbuh dan berkembang tentunya dikelola secara efisien dan efektif, hal tersebut perlu dilakukan untuk mengadapi persaingan ketat dalam dunia kesehatan. Rumah sakit bisa survive dalam menjalani competisi yang ada, tentunya pihak rumah sakit harus menghitung kembali tarif rumah sakit yang ada sebelumnya, yaitu untuk meminimalisir perhitungan tarif yang begitu tinggi dengan menggunakan model perhitungan tarif yang competitive, walaupun dengan tarif rendah tetapi tetap menjunjung tinggi suatu kualitas untuk bisa menjalankan visi dan misi sebuah rumah sakit, sehingga rumah sakit tidak mengalami kerugian dalam hal tarif maupun customer. Hal tersebut dilakukan untuk menarik minat kembali pasien lama dan pasien baru dalam memanfaatkan pelayanan yang ada.

Efisiensi biaya dari sisi demand adalah memberlakukan iuran biaya (cost sharing). Motivasi dibalik penerapan iuran biaya adalah asumsi bahwa demand yang tinggi atas layanan kesehatan merupakan penyebab utama tingginya biaya kesehatan. Tingkat pendidikan dan pengetahuan yang meningkat dan akses informasi yang meluas menyebabkan masyarakat sadar akan pentingnya kesehatan. Tersedianya perlindungan Jamkesmas dan tanpa / sedikit resiko keuangan, besar kemungkinan terjadinya moral hazard, penggunaan jasa yang tidak dibutuhkan dan tidak tepat. ${ }^{3}$ Tujuan iuran biaya adalah agar masyarakat bertindak rasional dan terhindar dari moral hazard. Namun, iuran biaya yang melampaui batas kemampuan peserta dapat menjadi paradok dari prinsip askes yang memproteksi penduduk dari kerugian keuangan dan sekaligus menurunkan akses peserta. ${ }^{4}$

Sugiarto $(2003)^{5}$ menyatakan bahwa adapun program yang menjadi tanggung jawab pemerintah, yaitu: a) program yang tergolong sebagai public goods, dan b) program pemeliharaan kesehatan bagi penduduk miskin. Badan Pusat Statistik (BPS) mencatat jumlah penduduk miskin pada 2008 sebanyak 35 juta jiwa. Garis kemiskinan dengan pengeluaran Rp.182.636/orang/bulan. Dana penanggulangan kemiskinan 2009 Rp 70 triliun. $^{6}$

Program Jamkesmas Secara umum Jamkesmas dibangun untuk memberikan akselerasi dalam peningkatan akses dan mutu pelayanan kesehatan terhadap seluruh masyarakat miskin dan tidak mampu agar tercapai derajat kesehatan masyarakat yang optimal secara efektif dan efisien. Secara khusus program ini ditujukan untuk meningkatkan cakupan masyarakat miskin dan tidak mampu guna mendapat pelayanan kesehatan di Puskesmas serta jaringannya dan di Rumah Sakit. Melalui program ini pula diharapkan akan terjadi proses penyelenggaraan pengelolaan keuangan yang transparan dan akuntable yang pada akhirnya akan berdampak kepada peningkatan kualitas pelayanan kesehatan bagi masyarakat miskin. Sasaran Program Jamkesmas adalah masyarakat miskin dan tidak mampu di seluruh Indonesia.

Garis kemiskinan di Provinsi D.I. Yogyakarta pada Maret 2009 sebesar Rp.211.978,- per kapital perbulan. Apabila dibandingkan dengan keadaan Maret 2008 yang sebesar Rp. 194.830,- per kapital perbulan, maka garis kemiskinan selama setahun yang lalu mengalami kenaikan sebesar 8,80 persen. Jumlah penduduk miskin, yaitu penduduk yang komunikasinya berada di bawah garis kemiskinan, pada Maret 2009 di Provinsi D.I. Yogyakarta terdapat 585,8 ribu orang. Jika dibandingkan dengan keadaan Maret 2008 yang jumlahnya mencapai 616,3 ribu orang, berarti jumla penduduk miskin berkurang sebanyak 30,5 ribu orang dalam setahun. Tingkat kemiskinan, yaitu persentase penduduk miskin dari seluruh penduduk, di Provinsi D.I. Yogyakarta pada Maret 2009 sebesar 17.23 persen. Apabila dibandingkan dengan keadaan Maret Tahun 2008 yang sebesar 18,32 persen berarti ada penurunan sebesar 1,09 persen selama setahun. ${ }^{7}$ 
Rumah sakit umum PKU Muhammadiyah Unit I Yogyakarta adalah salah satu rumah sakit swasta di Yogyakarta. Merupakan rumah sakit terakreditasi 12 bidang pelayanan dengan tipe $\mathrm{C}$ plus. Dibawah ini adalah tabel beberapa jenis pelayanan yang terdiri dari beberapa poliklinik spesialis dan sub spesialis yang ditawarkan oleh rumah sakit umum PKU Muhammadiyah Unit I Yogyakarta.

Tabel 1. Pelayanan yang Ditawarkan RS PKU Muhammadiyah Yogyakarta Unit I Tahun 2008

\begin{tabular}{cll}
\hline No. & \multicolumn{1}{c}{ Pelayanan } & \multicolumn{1}{c}{ Jumlah } \\
\hline 1. & Pelayanan Rawat Jalan. & 14 Poli Spesialis dan Sub pesialis. \\
\hline 2. & Pelayanan Rawat Inap. & 15 Ruang Waktu. \\
\hline 3. & Unit Penunjang Pelayanan Medis. & 11 Unit. \\
\hline 4. & Unit Penunjang Lainnya dan Unit on Medis. & 14 Unit. \\
\hline
\end{tabular}

Salah satu unit penunjang pelayanan medis di rumah sakit umum PKU Muhammadiyah Unit I Yogyakarta yang banyak dikunjungi oleh customer adalah IBS yang terdiri dari commatio cerebri, cabut plate post fraktur, Fractur Curis (orif cruis), Appendicitis (open), Apendicitis (Laparascopy) dan sexio caesarea. Berdasarkan data yang diperoleh dari IBS, jumlah pasien IBS tahun 2009 (dalam 6 bulan) sexio caesarea yang ikut dalam Jamkesmas yang menjalani pengobatan di IBS sebanyak 16 pasien.

Pegawai IBS (Instalasi Bedah Sentral) saat ini terdiri dari pegawai tetap medis 1 orang (pria), pegawai tetap paramedis 19 orang (12 pria, 7 wanita), serta pegawai tetap non medis 2 orang (pria) sehingga total pegawai di bagian IBS sebanyak 22 orang pegawai. Rumah Sakit PKU Muhammadiyah Unit I Yogyakarta menetapkan tarif operasi SC (seksio caesarea) dikelas III bertarif kurang lebih Rp. 4.000.000,- belum di tambah dengan biaya-biaya barang dan obat-obatan habis pakai, sedangkan tarif Paket Pelayanan Esensial (PPE) ditetapkan sebesar Rp. 1.230.429.,- ditambah lama hari rawat (LOS) sebesar 5,5 (data diatas di dapatkan dari hasil survei peneliti tanggal 20 Juli 2009). Di antara tarif operasi caesarea yang berasal dari rumah sakit dan pemerintah terdapat selisih cost sharing. Peneliti dalam hal ini hanya menghitung tarif operasi caesarea untuk re use saja, agar nilai cost sharingnya kecil. Selama ini pihak rumah sakit tidak pernah menghitung selisih yang ada.

Hai ini dapat menyebabkan rumah sakit jadi merugi, dengan demikian diperlukan penelitian lebih lanjut mengenai topik permasalahan di atas. Perlu ditinjau dari penerapan tarif berdasarkan Paket Pelayanan Esensial (PPE) yang mempengaruhi pembiayaan terhadap Jamkesmas itu sendiri. Tarif Paket Pelayanan Esensial (PPE) ini bisa lebih besar atau lebih kecil dari tarif Rumah Sakit sesuai dengan perhitungan real cost dan faktor-faktor apa saja yang mampu dieffisienkan untuk mengatasai permasalahan pembiayaan tersebut. Apakah masing-masing unit penerima dana sudah dapat mencukupi kebutuhan sesuai dengan besar pengeluarannya ataukah berlebih. Menyikapi adanya berbagai sumber dana yang bertujuan untuk mengatasi masalah pembiayaan kesehatan bagi keluarga miskin, perlu ada suatu mekanisme yang harmonis sehingga dapat menghasilkan manfaat yang lebih efektif dan efisien, serta setiap unit pemberi pelayanan kesehatan dapat memperoleh jumlah dana yang sesuai dengan kebutuhannya.

Melihat latar belakang pemasalahan tersebut maka diperlukan penelitian untuk mengevaluasi pelaksanaan uji coba penerapan tarif Paket Pelayanan 
Esensial (PPE) di RS PKU Muhammadiyah Unit I Yogyakarta karena di khawatirkan mengakibatkan kerugian financial yang cukup besar bagi RS PKU Muhammadiyah Unit I Yogyakarta mengingat jumlah Gakin yang cukup tinggi khususnya di bagian bedah dan kebidanan, dikhawatirkan penerapan tarif Paket Pelayanan Esensial (PPE) akan gagal karena banyak diagnosa penyakit yang tidak dimasukkan dalam tarif Paket Pelayanan Esensial (PPE) akibat adanya peluang bagi provider untuk mengajukan klaim secara fee for service. Dengan demikian dari penelitian ini diharapkan dapat diketahui keberhasilan tarif Paket Pelayanan Esensial (PPE) dalam mengendalikan biaya pelayanaan kesehatan bagi gakin di RS PKU Muhammadiyah Unit I Yogyakarta serta kemungkinannya untuk dapat diterapkan dalam jangka waktu panjang di RS PKU Muhammadiyah Unit I Yogyakarta.

\section{METODE PENELITIAN}

Jenis penelitian yang digunakan adalah deskriptif dengan pendekatan kualitatif. Penelitian deskriptif bertujuan untuk menggambarkan atau mendeskripsikan mengenai tarif yang sesungguhnya terkait dengan tindakan operasi caesarea kelas III di RS PKU Muhammadiyah Unit I Yogyakarta.

Alat atau instrumen yang digunakan dalam penelitian ini berupa pedoman wawancara yang dibuat sendiri oleh peneliti, sesuai dengan keperluan peneliti berdasarkan konsep dan teori. Subyek dalam penelitian ini adalah Kepala Bagian Keuangan, pegawai Instalasi Bedah Sentral (IBS) dan pasien.

\section{HASIL PENELITIAN DAN PEMBAHASAN}

\section{a. Hasil Penelitian}

1) Biaya yang Sesungguhnya Terjadi Terkait dengan Tarif Paket Pelayanan Esensial (PPE)

a) Jumlah Pasien Operasi Caesarea

Jumlah pasien Operasi caesarea kelas III di Rumah Sakit PKU Muhammadiyah Yogyakarta pada bulan Januari-Juni (2009) adalah 16 pasien.

Tabel 1. Jumlah Pasien Operasi Caesarea Kelas III Januari-Juni (2009)

\begin{tabular}{ccc}
\hline No & Bulan & Jumlah Pasien \\
\hline 1. & Januari & - \\
\hline 2. & Februari & 1 \\
\hline 3. & Maret & 2 \\
\hline 4. & April & 2 \\
\hline 5. & Mei & 6 \\
\hline 6. & Juni & 5 \\
\hline & Jumlah & 16 orang pasien \\
\hline
\end{tabular}

Berdasarkan tabel di atas terlihat bahwa pasien operasi caesarea kelas III jumlah yang tertinggi terdapat pada bulan Mei dengan jumlah 6 pasien dan jumlah terendah yaitu berada pada bulan Januari tidak ada 
pasien. Jumlah keseluruhan pasien caesarea kelas III pada tahun 2009 adalah 16 orang.

\section{b) Perhitungan Tarif Operasi Caesarea Kelas III dengan Metode Real Cost}

Perhitungan tarif operasi caesarea kelas III di IBS dilakukan oleh bagian keuangan, kemudian baru diserahkan ke bagian direktur rumah sakit dan barulah rumah sakit dapat menentukan kebijakan tarif caesarea. Perlu diketahui bahwa penentuan tarif caesarea yang dilakukan RS PKU Muhammadiyah Unit I Yogyakarta juga mempertimbangkan dari segi kompetitif dengan rumah sakit lainnya. Tarif caesarea kelas III yang ditetapkan oleh RS PKU Muhammmadiyah Unit I Yogyakarta terdiri dari biaya pendaftaran Rp 7.500, tarif operasi rumah sakit $R p$ 1.300.000, material bahan habis pakai $R p$ 683.000, jasa dokter bedah Rp 750.000 jasa tenaga kerja perawat Rp 300.000.

Perhitungan tarif dengan menggunakan metode Real Cost terdiri dari biaya langsung dan tidak langsung dimana komponen biaya yang digunakan untuk menentukan tarif caesarea kelas III terdiri dari 6 komponen biaya yang terdiri dari biaya pendaftaran, biaya BHP (bahan habis pakai), biaya depresiasi bangunan, biaya depresiasi alat medis dan non medis, biaya listrik, biaya pemeliharaan dan biaya tenaga kerja. ${ }^{8}$

Biaya langsung adalah biaya secara langsung yang memproduksi barang atau jasa caesarea kelas III di Instalasi Bedah Sentral pada RS PKU Muhammadiyah Unit I Yogyakarta. Biaya yang dimaksud yaitu Biaya pendaftaran Rp 7.500,- Biaya BHP (Biaya Habis pakai) dari operasi caesarean kelas III Rp 638.000,- dan Biaya jasa dokter Rp $750.000,-$. Jadi total keseluruhan biaya langsung adalah $\mathrm{Rp} 1.395 .500$,-

Biaya tidak langsung adalah biaya yang tidak langsung dalam hubungan dengan kegiatan caesarea berupa listrik, biaya depresiasi bangunan, biaya tenaga kerja (gaji), biaya depresiasi alat medis dan non medis, biaya pemeliharaan yang dihitung berdasarkan jumlah pasien dalam satu tahun (2009).

Pengeluaran biaya listrik RS PKU Muhammadiyah Unit I Yogyakarta untuk Instalasi Bedah Sentral (IBS) selama JanuariDesember (2009) adalah Rp 12.067.482,--

Biaya Listrik IBS (2009) : Biaya total keseluruhan pemakaian Listrik RS PKU Muhammadiyah (2009) x Biaya Listrik IBS (2008) : $2: \Sigma$ pasien operasi caesarea kelas III (2009). Tarif yang dikenakan kepada setiap pasien adalah $\mathrm{Rp} 12.067 .482$ : $\mathrm{Rp} 361.971 .974$ x $\mathrm{Rp}$ 12.067.482 : $2: 16=\operatorname{Rp} 12.579,-$. Jadi tarif listik yang dikenakan kepada setiap pasien sebesar Rp 12.579,-

Biaya depresiasi bangunan sama juga dengan biaya penyusutan bangunan di Instalasi Bedah Sentral (IBS) selama Januari-Desember (2009). Luas ruangan IBS $x$ depresiasi bangunan di IBS : umur ekonomis bangunan $\mathrm{x}$ luas ruangan IBS : $\Sigma$ pasien operasi caesarea kelas III (2009) : $2=240 \mathrm{M}^{2} \times \operatorname{Rp} 3.000 .000: 10 \times 240 \mathrm{M}^{2}: 16: 2=$ Rp 37.500,- . Jadi tarif depresiasi bangunan yang dikenakan kepada setiap pasien sebesar Rp 37.500,-

Gaji yang diperhitungkan dalam biaya ini adalah jumlah tenaga medis yang ada di Instalasi Bedah Sentral (IBS) yaitu sebanyak 22 orang tenaga medis. Gaji perbulan untuk satu orang tenaga medis sebesar Rp 1.615.293 sehingga dalam setahun gaji tenaga medis perorang adalah $\mathrm{Rp}$ 19.383.520. tarif yang dikenakan setiap pasien 
adalah Gaji perbulan tenaga medis x 6 (bulan) : 22 orang : $\Sigma$ pasien operasi caesarea kelas III $(2009)=R p 1.615 .293 \times 6: 22: 16=R p$ 27.533

Biaya ini merupakan biaya penyusutan fasilitas yang terdapat di Instalasi Bedah Sentral (IBS) selama 6 bulan (2009) sebesar Rp 19.249.969. tarif yang diberikan kepada setiap pasien adalah Biaya fasilitas IBS (2009) : umumr ekonomis : $\sum$ pasie operasi caesarean kelas III (2009) = Rp 19.249.969: $10: 16=$ Rp 120.312,-

Biaya pemeliharaan ditelusuri dari fasilitas medis atau non medis di Instalasi Bedah Sentral (IBS) bulan Januari-Desember (2009) yaitu sebesar Rp 22.993.000. Tarif setiap pasien adalah Luas bangunan IBS : Luas Total RS PKU Muhammadiyah $x$ Biaya pemeliharaan $(2008): 2: \sum$ pasien cesarea kelas III (2009) = Rp $240 \mathrm{M}^{2}: 5568 \mathrm{M}^{2} \mathrm{x}$ Rp 22.993.000 : $2: 16=\operatorname{Rp~30.971,-~}$. Jadi tarif biaya pemeliharaan yang dikenakan setiap pasien sebesar $\mathrm{Rp} 30.971,-$. Biaya tidak langsung caesarea kelas III adalah = biaya listrik + biaya depresiasi bangunan + gaji + biaya depresiasi alat medis dan non medis + biaya pemeliharaan $=R p 12.572+R p 37.500+R p 27.533+R p 120.312+$ Rp 30.971,- = Rp 228.888,-

Total tarif adalah jumlah keseluruhan tarif yang harus dikeluarkan setiap pasien caesarea kelas III di Instalasi Bedah Sentral (IBS) pada RS PKU Muhammadiyah Yogyakarta tahun (2009), yaitu terdiri dari biaya langsung dan tidak langsung $=R p 1.395 .500+R p 228.888=R p$ 1.624.388,-

\section{2) Faktor-Faktor yang Bisa Dieffisiensikan adalah :}

a) Meninjau kembali biaya langsung yang mungkin bisa untuk dieffesiensikan berdasarkan kesepakatan bersama antara dokter dengan pihak RS PKU Muhammadiyah Unit I Yogyakarta.

b) Meninjau kembali biaya tak langsung dengan meninjau faktor-faktor apa saja yang masih bisa diefesiensikan seperti gaji pegawai, biaya pemeliharaan, biaya listrik, biaya depresiasi bangunan dan lain-lainnya berdasarkan kesepakatan bersama pihak RS PKU Muhammadiyah Unit I Yogyakarta.

c) Peningkatan jumlah pasien khususnya di bagian operasi caesarea. Diharapkan pihak rumah sakit dapat menghitung kembali tarif yang ada, yang mungkin tidak memerlukan watu yang lama untuk melakukannya, karena Rumah Sakit PKU Muhammadiyah Yogyakarta juga menggunakan metode real cost dalam perhitungan tarifnya, hanya perhitungan komponen biaya overheadnya saja yang di tambah dalam melakukan evaluasi perhitungan tarif yang ada.

\section{3) Persepsi Pemberi Pelayanan Kesehatan (PPK)}

Subyek penelitian ini adalah Kepala Bagian Keuangan, pegawai Instalasi Bedah sentral (IBS) di RSU PKU Muhammadiyah Unit I Yogyakarta. Subyek penelitian diberi kesempatan untuk mengemukakan pendapatnya sesuai dengan pedoman wawancara yang telah disediakan sebelumnya oleh peneliti.

Penerapan tarif Paket Pelayanan Esensial (PPE) bagi pelayanan pasien kelas III di RS PKU Muhammadiyah Unit I Yogyakarta mendapatkan tanggapan dari hasil wawancara dengan Kepala Bagian Keuangan :

“....paket atau tarif Paket Pelayanan Esensial (PPE) Jamkesmas masih sangat jauh dibawah tarif $R S$, apalagi tarif RS PKU digolongkan 
tarif untuk RS tipe $C$ sehingga yang timbul di RS PKU menjadi besar bila dibandingkan dengan tarif pengganti dari Jamkesmas...."

Penerapan tarif Paket Pelayanan Esensial (PPE) di bagian Instalasi Bedah Sentral (IBS) khususnya bagi pasien operasi Caesarea mendapatkan pelayanan mutu yang sama tanpa membandingkan pasien miskin atau biasa. Hal ini terungkap berdasar pada wawancara dengan Kepala Bagian Keuangan:

"....mutu pelayanan relatif sama, hanya dibedakan dari akomodasinya yaitu khusus Jamkesmas menempati kelas III....”.

Berdasarkan wawancara terdapat beberapa pendapat dari Kepala Bagian Keuangan dan satu orang staf Instalasi Bedah Sentral (IBS), yaitu sebagi berikut:

“....untuk masalah tarif operasi caesarea di PKU lebih murah dibandingkan dengan rumah sakit lain karena kita menyesuaikan kebijakan dengan tarif yang ada dan sesuai dengan kondisi kita, beda dengan rumah sakit lain yang secara penyusutan lebih besar dari pada kita sehingga membuat tarif operasi caesarea di PKU lebih murah...."

Hal itu juga dibenarkan dari hasil wawancara terhadap pasien yang memilih untuk menjalankan operasi caesarea di RS PKU Muhammadiyah Unit I Yogyakarta, yitu sebagi berikut :

“....lebih memilih RS PKU ini dikarenakan selain Rumah Sakit Islam tarif yang relatif murah...."

Mengenai sistem perhitungan yang diterapkan di RSU PKU Muhammadiyah Unit I Yogyakarta untuk bagian Instalasi Bedah Sentral (IBS) khususnya untuk tindakan operasi caesarea adalah berdasarkan pada bahan habis pakai dan dari biaya tenaga kerjanya. Hal ini terungkap dari hasil wawancara pendahuluan dengan Kepala Bagian Keuangan RSU PKU Muhammadiyah Unit I Yogyakarta :

"....bahwa sistem perhitungan yang kami gunakan untuk menghitung tarif di unit IBS adalah berdasar pada bahan habis pakai dan biaya tenaga kerja, rumah sakit menetapkan tarif sebesar Rp 1.230.429...."

Perlakuan cost sharing di unit Instalasi Bedah Sentral (IBS) khususnya operasi caesarea adalah bahwa selisih yang ada antara tarif rumah sakit dengan tarif pemerintah ditanggung oleh rumah sakit, pasien tidak boleh dikenakan biaya karena akan bertentangan dengan UU Jamkesmas yang ada, walaupun rumah sakit akan merugi akan hal ini.

\section{b. Pembahasan}

\section{1) Selisih Tarif}

Berdasarkan penelitian ini dapat diketahui bahwa tarif yang dikenakan oleh pihak RSU PKU Muhammadiyah Unit I Yogyakarta adalah sebesar Rp.1.230.429 Penentuan tarif untuk tindakan operasi caesarea ini adalah menggunakan metode real cost. Secara umum hasil analisis metode real cost adalah digunakan untuk penentuan harga pokok produk/jasa, 
pengendalian biaya (berhubungan dengan anggaran), pengambilan keputusan, dan mengidentifikasi sistem akuntansi biaya. ${ }^{8}$

Tabel 2. Perbandingan Tarif Operasi Caesarea Anatara Paket Pelayanan Esensial (PPE) Jamkesmas, Real Cost, dan Tarif RS PKU Muhammadiyah Unit Yogyakarta

\begin{tabular}{|c|c|c|c|}
\hline & $\begin{array}{c}\text { Paket Pelayanan } \\
\text { Esensial (PPE) } \\
\text { Jamkesmas } \\
\end{array}$ & Real Cost & Tarif RS PKU \\
\hline Paket SC & Rp 1.230.429 & Rp 1.624.388 & Rp 3.585.500 \\
\hline Akomodasi ibu & - & $\begin{array}{l}5,5 \times \operatorname{Rp~} 40.000 \\
=\operatorname{Rp} 220.000\end{array}$ & $\begin{array}{l}5,5 \times \operatorname{Rp} 40.000 \\
=\operatorname{Rp} 220.000\end{array}$ \\
\hline Akomodasi anak & - & $\begin{array}{l}5,5 \times \operatorname{Rp~} 40.000 \\
=\operatorname{Rp} 220.00\end{array}$ & $\begin{array}{l}5,5 \times \operatorname{Rp} 40.000 \\
=\operatorname{Rp} 220.000\end{array}$ \\
\hline Visite ibu & - & $\begin{array}{l}4 \times \operatorname{Rp} 50.000 \\
=\operatorname{Rp} 200.000\end{array}$ & $\begin{array}{l}4 \times \operatorname{Rp} 50.000 \\
=\operatorname{Rp} 200.000\end{array}$ \\
\hline Visite anak & - & $\begin{array}{l}4 \times \operatorname{Rp} 50.000 \\
=\operatorname{Rp} 200.000\end{array}$ & $\begin{array}{l}4 \times \operatorname{Rp} 50.000 \\
=\operatorname{Rp} 200.000\end{array}$ \\
\hline Pendaftaran & - & $\operatorname{Rp} 7.500$ & $\operatorname{Rp} 7.500$ \\
\hline Tindakan operasi & - & $\operatorname{Rp} 1.900 .000$ & Rp 1.900.000 \\
\hline $\begin{array}{ll}\text { Bahan } & \text { Habis } \\
\text { Pakai (BPH) }\end{array}$ & - & $\begin{array}{l}\operatorname{Rp} 638.000+ \\
\operatorname{Rp} 150.000 \\
=\operatorname{Rp} 788.000\end{array}$ & $\begin{array}{l}\operatorname{Rp} 638.000+ \\
\operatorname{Rp} 150.000 \\
=\operatorname{Rp} 788.000 \\
\end{array}$ \\
\hline Biaya listik & - & $\operatorname{Rp} 12.572$ & Rp 12.572 \\
\hline $\begin{array}{l}\text { Biaya depresiasi } \\
\text { bangunan }\end{array}$ & - & Rp 37.500 & Rp 37.500 \\
\hline Gaji pegawai & - & Rp 27.533 & Rp 27.533 \\
\hline $\begin{array}{l}\text { Biaya depresiasi } \\
\text { alat medis dan } \\
\text { non medis }\end{array}$ & - & Rp 120.312 & Rp 120.312 \\
\hline $\begin{array}{l}\text { Biaya } \\
\text { pemeliharaan }\end{array}$ & - & Rp 30.971 & Rp 30.971 \\
\hline Margin 25\% & - & - & $\begin{array}{l}\text { Ditambah margin } 25 \% \\
(\mathrm{Rp} 3.764 .388)=\mathrm{Rp} \\
941.097\end{array}$ \\
\hline TOTAL & Rp 1.230.429 & Rp 3.764.388 & Rp 4.705 .485 \\
\hline
\end{tabular}

Berdasarkan tabel di atas bahwa tarif Paket Pelayanan Esensial (PPE) Jamkesmas terkait dengan tindakan operasi caesarea adalah sbesar Rp 1.230.429, tarif operasi caesarea dengan menggunakan metode real cost sebesar Rp 3.764.388 sedangkan tarif yang ditetapkan oleh RS PKU Muhammadiyah Unit I Yogyakarta adalah sebesar Rp 4.705.485 sehingga didapatkan selisih diantara tarif Paket pelayanan Esensial (PPE) Jamkesmas dengan tarif real cost sebesar Rp 2.533.959 dan ada selisih antara tarif Paket Pelayanan Esensial (PPE) Jamkesmas dengan tarif yang telah ditetapkan pihak RS sebesar Rp 3.475.056. Berdasarkan data di atas dapat dikatakan bahwa rumah sakit mengalami kerugian karena harus membayar selisih dari kedua tarif tersebut. Trisnantoro $(2006)^{9}$ menyatakan bahwa tarif dapat berada di bawah, sama, atau di atas unit cost. Apabila tarif berada dibawah unit cost berarti rumah sakit mengalami kerugian. 
Operasi caesarea merupakan salah satu dari Paket Pelayanan Esesensial (PPE) Jamkesmas. Namun, rumah sakit masih memiliki paket pelayanan lainnya terkait dengan jamkesmas seperti pada CT.Scan, Hemodialisa dan lain-lain. Rumah Sakit PKU Muhammadiyah Yogyakarta masih bisa bangkit dari kerugian yang ada karena mendapat subsidi dari pelayanan kesehatan lainnya. Paket pelayanan esensial merupakan sistem paket, dimana sistem paket tersebut memiliki sisi negatif dan positifnya, dimana bila dari segi negatif bahwa rumah sakit harus bisa menekan biaya produksi untuk bisa bekerja sama dengan pihak Jamkesmas. Sisi positifnya dapat dilihat dari terjadi peningkatan captive market, berkurangnya bad debt (piutang ragu-ragu), terkait dengan visi misi Rumah Sakit PKU Muhammadiyah tentang kaum dhuafa, terdapat anggaran untuk dana sosial terkait dengan Jamkesmas.

Standar costing tersebut salah satunya adalah menggunakan metode real cost yang mana metode tersebut terdiri dari tiga komponen; yaitu bahan habis pakai, biaya tenaga kerja, dan biaya overhead. Ketiga komponen tersebut merupakan unit cost atau harga pokok penjualan, dari komponen tersebut rumah sakit menetapkan harga pokok penjualannya. Namun, yang terjadi di Rumah Sakit PKU Muhammadiyah Unit I Yogyakarta, hanya menghitung dari sisi biaya bahan habis pakai dan biaya tenaga kerja saja, biaya overhead tidak dihitung sehingga tarif yang diberikan oleh rumah sakit rendah. Oleh karena itu, dibutuhkan data informasi yang akurat, sehingga pihak rumah sakit tidak dirugikan.

Penentuan tarif operasi caesarea kelas III di Instalasi Bedah Sentral (IBS) di RS PKU Muhammadiyah Unit I Yogyakarta menggunakan metode real cost, dimana untuk menggambarkan biaya-biaya yang terjadi ditentukan berdasarkan biaya langsung dan biaya tidak langsung, dan hasil dari real cost adalah harga satuan (unit cost). Kelebihan dari metode ini adalah cara perhitungan lebih sederhana, biaya langsung dan tidak langsung dapat disesuaikan dengan ada tidaknya tempat pelayanan, cocok digunakan di rumah sakit karena cara perhitungan metode real cost lebih sederhana. Kekurangan metode ini adalah pengumpulan biaya langsung dan tidak langsung cukup rumit yaitu pengumpulan data dasar. ${ }^{8}$

Rumah sakit PKU Muhammadiyah Unit I Yogyakarta dalam menentukan tarif juga mempertimbangan keadaan pasar dan mempertimbangkan persaingan pasar dan RS PKU Muhammadiyah Unit I Yogyakarta beranggapan bahwa, biaya adalah tarif, tapi menurut teori yang ada biaya dan tarif itu memliki perbedaan. Biaya merupakan herga perolehan yang dikorbankan atau digunakan dalam rangka memperoleh penghasilan dan akan dipakai dalam perguruan penghasilan. ${ }^{10}$ Trisnantoro $(2005)^{2}$ menyatakan tarif adalah sejumlah uang yang dibayarkan sebagai pengganti sebagai balas jasa atau barang atau jasa yang diterimanya.

Rumah Sakit PKU Muhammadiyah Unit I Yogyakarta dalam menghitung tarif operasi caesarea kales III hanya menghitung beberapa struktur biaya saja yaitu biaya jasa rumah sakit, jasa dokter dan biaya habis pakai. Raymond (2001) $)^{8}$ menyatakan bahwa biaya overhead, biaya bahan habis pakai, biaya tenaga kerja merupakan biaya langsung dan tidak langsung dalam perhitungan tarif dengan menggunakan metode real cost.

\section{2) Faktor-Faktor yang Bisa Dieffisiensikan adalah :}


Tabel 3. Faktor-Faktor yang Dieffisiensikan Oleh Pihak RS PKU Muhammadiyah PKU Unit I Yogyakarta

\begin{tabular}{|c|c|c|}
\hline No. & $\begin{array}{l}\text { Faktor-faktor yang } \\
\text { dieffisiensikan }\end{array}$ & Alasan \\
\hline 1. & $\begin{array}{l}\text { Biaya Langsung } \\
\text { pendaftaran, BHP, biaya } \\
\text { dokter) }\end{array}$ & $\begin{array}{l}\text { - Biaya pendaftaran bisa dihilangkan karena } \\
\text { bisa disubsidi silang dari unit lainnya. } \\
\text { - Biaya Habis Pakai (BHP), berupa obat- } \\
\text { obatan di buat dalam bentukan paket, } \\
\text { karena ada obat-obatan yang diberikan } \\
\text { dalam jumlah banyak yang hanya di } \\
\text { konsumsi dalam berapa hari namun } \\
\text { diberikan berlebihan. } \\
\text { - Biaya dokter, jasa dokter bisa di tinjau lagi } \\
\text { karena sebelum menjalankan atau terikat } \\
\text { dengan kebijakan Jamkesmas RS dokter } \\
\text { pun sepakat untuk mengurangi } 50 \% \text { dari } \\
\text { subsidi yang sebenarnya berhubungan } \\
\text { dengan kemaslahatan masyarakat ekonomi } \\
\text { bawah. }\end{array}$ \\
\hline
\end{tabular}

2. Biaya tidak langsung (biaya Karena semua biaya yang termasuk dalam listrik, biaya depresiasi biaya langsung danbiaya tidak langsung bangunan, gaji, biaya mempengaruhi terhadap unit cost jika tidak depresiasi alat medis dan ditekan maka otomatis biaya tersebut non medis, biaya mempengaruhi unit cost. Apabila unit cost pemeliharaan) tinggi maka harga yang tinggi tidak kompetitif dengan biaya Jamkesmas.

3. Menaikan kunjungan pasien Semakin besar kunjungan pasien maka semakin mempengaruhi terhadap total biaya dalam perhitungan tarif, otomatis biaya unit cost akan kompetitif dengan biaya Jamkesmas.

Diharapkan pihak rumah sakit dapat menghitung kembali tarif yang ada, yang mungkin tidak memerlukan waktu yang lama untuk melakukannya, karena Rumah Sakit PKU Muhammadiyah Unit I Yogyakarta juga menggunakan metode real cost dalam perhitungan tarifnya, hanya perhitungan komponen biaya overheadnya saja yang di tambah dalam melakukan evaluasi perhitungan tarif yang ada.

\section{3) Persepsi Pemberi Pelayanan Kesehatan (PPK)}

Penerapan tarif Paket Pelayanan Esensial (PPE) bagi pelayanan pasien kelas III di RS PKU Muhammadiyah Unit I Yogyakarta mendapatkan tanggapan dari hasil wawancara dengan Kepala Bagian Keuangan bahwa paket atau tarif Paket Pelayanan Esensial (PPE) Jamkesmas masih sangat jauh dibawah tarif RS, apalagi tarif RS PKU digolongkan tarif untuk RS tipe $C$ sehingga yang timbul di RS PKU menjadi besar bila dibandingkan dengan tarif pengganti dari Jamkesmas. Pihak RS pun menginginkan ada nya kenaikan tipe RS yang awal nya bertipe $C$ menjadi $B$ disesuaikan dengan penetapan tarif yang ada.

Perbandingan selisih tarif yang jauh antara Paket Pelayanan Esensial (PPE) Jamkesmas dengan tarif yang ditetapkan oleh RS PKU Muhammadiyah Unit I Yogyakarta, tidak mempengaruhi mutu pelayanan kepada pasien hanya saja memang telah ketentuan pasien Jamkesmas 
menempati ruangan kelas III namun tak menjadikan alasan mutu pelayanan bagi pasien dikurangkan. Pihak RS pun sadar dengan adanya selisih yang jauh tapi tetap bekerjasama dengan pihak Jamkesmas disebabkan karena Sebagai tantangan RS PKU Muhammadiyah Unit I Yogyakarta untuk mengevaluasi selisih tarif yang ada, pihak Jamkesmas berani memberikan ganti rugi sebesar Rp 1.230.429 kenapa pihak RS PKU Muhammadiyah Unit I Yogyakarta tidak bisa mengkriet tarif yang ada. Kaptik market jelas atau sasaran pasar yang ingin dituju bener-benar jelas. Terkait dengan persaingan antar Rumah Sakit.

\section{SIMPULAN DAN SARAN}

\section{a. Simpulan}

1) Tarif Paket Pelayanan Esensial (PPE) Jamkesmas terkait dengan tindakan operasi caesarea adalah sebesar Rp 1.230.429, tarif operasi caesarea dengan menggunakan metode real cost sebesar Rp 3.764 .388 sedangkan tarif yang ditetapkan oleh RS PKU Muhammadiyah Unit I Yogyakarta adalah sebesar $\mathrm{Rp}$ 4.705.485 sehingga didapatkan selisih diantara tarif Paket pelayanan Esensial (PPE) Jamkesmas dengan tarif real cost sebesar Rp 2.533.959 dan ada selisih antara tarif Paket Pelayanan Esensial (PPE) Jamkesmas dengan tarif yang telah ditetapkan pihak RS sebesar Rp 3.475.056.

2) Faktor-faktor yang bisa di efisiensikan adalah Meninjau kembali biaya langsung yang mungkin bisa untuk dieffesiensikan berdasarkan kesepakatan bersama antara dokter dengan pihak RS PKU Muhammadiyah Unit I Yogyakarta. Meninjau kembali biaya tak langsung dengan meninjau faktor-faktor apa saja yang masih bisa dieffesiensikan seperti gaji pegawai, biaya pemeliharaan, biaya listrik, biaya depresiasi bangunan dan lain-lainnya berdasarkan kesepakatan bersama pihak RS PKU Muhammadiyah Unit I Yogyakarta.

3) Penerapan tarif Paket Pelayanan Esensial (PPE) bagi pelayanan pasien kelas III di RS PKU Muhammadiyah Unit I Yogyakarta mendapatkan tanggapan dari hasil wawancara dengan Kepala Bagian Keuangan bahwa paket atau tarif Paket Pelayanan Esensial (PPE) Jamkesmas masih sangat jauh dibawah tarif RS, apalagi tarif RS PKU digolongkan tarif untuk RS tipe C sehingga yang timbul di RS PKU menjadi besar bila dibandingkan dengan tarif pengganti dari Jamkesmas.

\section{b. Saran}

Bagi RSU PKU Muhammadiyah Unit I Yogyakarta:

1) Melakukan evaluasi terhadap komponen biaya langsung dan biaya tidak langsung

2) Menetapkan paket khusus terhadap tindakan operasi caesarea, terutama pada Biaya Habis Pakai (BHP) berupa obat-obatan.

3) Menaikan tipe RS dari $C$ menjadi $B$ untuk penyesuaian biaya.

\section{DAFTAR PUSTAKA}

1. Mukti, 2001

2. Trisnantoro, L., Memahami Penggunaan IImu Ekonomi dalam Manajemen Rumah Sakit, Gadjah Mada University Press, Yogyakarta. 2005 
3. Chusnun, SP., Efisiensi Layanan Kesehatan: http://www.pamjaki.org, diambil pada tanggal 15 Juli 2009, Yogyakarta. 2009

4. Patriaji, 2009

5. Sugiarto, A., Julita Hendrartini., Ali Gufron Mukti, Persepsi Stakeholder Terhadap Perubahan Pola Kontrak Kapitasi Total Biaya Pelayanan Kesehatan Peserta Wajib PT.Askes dari Basis Kabupaten ke Basis Puskesmas di KabupatenKuloprogo, Jurnal Manajemen Pelayanan Kesehatan, Volume 06/ No.04/2003.

6. Bonasir, Rohmatin, Laporan Khusus Problematika Kemiskinan di Indonesia: http:// www.bbc.co.uk, diambil pada tanggal 28 Mei 2009, Yogyakarta. 2009

7. BPS, 2009

8. Raymond, T., Perhitungan Unit Cost untuk Orang Miskin di Rumah Sakit, Pusat Manajemen Pelayanan Kesehatan FK-UGM, Yogyakarta. 2001

9. Trisnantoro, L., Memahami Penggunaan IImu Ekonomi dalam Manajemen Rumah Sakit, Gajah Mada University Press, Yogyakarta. 2006

10. Supriyono, 1999 